\title{
VAKSINASI BCG MENINGKATKAN AKTIVITAS FAGOSITOSIS DAN SEKRESI REACTIVE OXYGEN INTERMEDIATE (ROI) PADA MAKROFAG PERITONEUM KUCING YANG DIINFEKSI DENGAN Mycobacterium tuberculosis
}

\section{BCG VACINATION INCREASED PHAGOSISTOCYTE ACTIVITIES AND REACTIVE OXYGEN INTERMEDIATE (ROI) SECRETION IN CAT PERITONEUM MACROPHAGES WHICH INFECTED BY Mycobacterium tuberculosis}

\author{
Ida Tjahajati \\ Bagian IImu Penyakit Dalam, Fakultas Kedokteran Hewan, Universitas Gadjah Mada, Yogyakarta,
}

\begin{abstract}
The aim of this experiment is to study the effect of BCG vaccination on phagocyte activity and $R O$ I secretion in cat peritoneum macrophages which infected with M.tuberculosis. The experiment used twenty four healthy cats. The animals were divided in 2 groups, 12 cats in each group. Group I were vaccinated with BCG, group II were control group which unvaccinated. BCG vaccination was done twice in two weeks interval. Two days after vaccination each cat was infected by 105 cfu M.tuberculosis intraperitoneally. The activity of macrophages were measured at 1st, 2nd, 12th, and 24th, after infection using in vitro latex bead phagocyte and NBT reduction assay. Three cats were used to measure the macrophage activity in each period, using triplicate sample for each cat. The results of the experiment showed that the phagocyte activity and $R O I$ secretion increased significantly in vaccination group $(P<0.01)$ compared with the control group, and these activities reached to the plateau level at 2 weeks after infection. Although these enhanced activities were gradually diminished thereafter, higher levels of these activities were consistently observed until the end of experiment compared with control group. BCG vaccination increased the cellular immunity especially phagocyte and ROI secretion activities of peritoneual macrophages in cat infected with M.tuberculosis
\end{abstract}

Key words: BCG, phagocyte, ROI, M.tuberculosis, cat

\section{PENDAHULUAN}

Mycobacterium tuberculosis (M. tuberculosis) merupakan kuman tahan asam penyebab kematian hampir 3 juta manusia, dan terdapat 8-12 juta kasus baru setiap tahunnya (1). Penyakit yang berlangsung secara menahun (kronik) tersebut, oleh World Health Organization (WHO) diperkirakan telah menyerang sepertiga penduduk dunia, dan mempunyai potensi berkembang ke arah penyakit reaktif (2). Dengan berkembangnya human immunodeficiency virus/ acquired immunodeficiency syndrome (HIVIAIDS) serta adanya masalah kekebalan kuman terhadap berbagai obat tuberkulosis (multi-drugs resistant M.tuberculosis, MDRTB), menyebabkan tuberkulosis menjadi masalah kesehatan dunia. Di Indonesia, menurut Survei Kesehatan Rumah Tangga Departemen Kesehatan Republik Indonesia pada tahun 1992, diperkirakan 175.000 orang meninggal setiap tahunnya, dan terdapat sekitar 500.000 kasus baru. Tuberkulosis merupakan penyebab kematian nomor dua terbesar di Indonesia setelah penyakit kardiovaskuler, dan merupakan penyebab kematian nomor satu dari kelompok

Jurnal Kedokteran Brawijaya, Vol. XXI, No.2, Agustus 2005 Korespondensi: Ida Tjahajati; Bagian IImu Penyakit Dalam, FKH Universitas Gadjah Mada Yogyakarta; Email: ida_tjahajati@yahoo.com atau itjah@plasa.com penyakit infeksi (3). Mycobacterium dari M.tuberculosis complex yang menyerang manusia telah diketahui juga dapat menyebabkan tuberkulosis bentuk pulmonari, gastrointestinal, atau bentuk menyebar pada hewan piaraan termasuk kucing $(4,5,6,7)$.

Usaha pencegahan terhadap tuberkulosis telah lama diupayakan yaitu dengan melakukan vaksinasi menggunakan M.bovis galur Bacillus Calmette-Guerin (BCG) yang telah dilemahkan. Vaksin ini pertama kali digunakan pada manusia tahun 1921, selanjutnya aplikasi penggunaannya meluas ke berbagai negara di dunia dengan tingkat protektivitas yang bervariasi $(8,9)$. Sifat imunopotensiator BCG pada hewan percobaan telah banyak dipelajari dan terbukti dapat meningkatkan reaktivitas imunologis dengan berbagai mekanisme. Bacillus Calmette-Guerin dapat merubah beberapa komponen respon imun, mengubah beberapa tipe sel, dan dapat mendorong terjadinya efek stimulasi atau penghambatan pada sistem imun tergantung pada bagaimana cara menggunakannya (10). Selain memacu respon imun yang diperantarai sel T, BCG juga diketahui dapat meningkatkan jumlah limfosit. Secara in vitro pemberian BCG dapat meningkatkan jumlah limfosit CD4+ yang terbukti dengan meningkatnya jumlah sel-sel blast CD4+ dalam kultur (11). Puncak proliferasi limfosit terjadi 2 minggu 
setelah infeksi pada hewan coba yang diinfeksi dengan BCG (12).

Pengaruh BCG terhadap kemampuan fagositosis dan daya bunuh makrofag pada infeksi Staphylococcus aureus dan efeknya dalam meningkatkan produksi tumor necrosis factor alpha (TNF-a) oleh makrofag telah dilapor kan oleh Djamiatun et al. (13). Peningkatan aktivitas pembunuhan terhadap intraerythrocytic Plasmodium yoelii secara in vitro karena efek BCG juga telah dilaporkan oleh Supargiono (14). Laporan lain mengenai efek BCG terhadap pembunuhan Plasmodium berghei oleh makrofag didemontrasikan oleh Wijayanti (15). Hasil penelitian terdahulu menunjukkan bahwa infeksi tuberkulosis pada kucing juga mengikuti paradigma Th1 dan Th2 yang melibatkan aktivitas makrofag dan T helper (16). Meskipun BCG sampai saat ini digunakan di lapangan dan telah diketahui bersifat imunopotensiator, namun bagaimana pengaruhnya terhadap imunitas seluler khususnya aktivitas makrofag dalam fagositosis dan sekresi ROI pada kucing belum pernah dilaporkan.

Pada penelitian ini dipelajari bagaimana pengaruh vaksinasi BCG terhadap aktivitas makrofag yang meliputi aktivitas fagositosis dan sekresi ROI pada kucing yang diinfeksi M.tuberculosis. Telah diketahui mekanisme respon imun terhadap infeksi M.tuberculosis diperankan oleh imunitas seluler yaitu sel makrofag dan sel $\mathrm{T}$ ( $T$-cell mediated immunity), dengan mekanisme utama meningkatnya aktifitas sel T dan makrofag $(17,18,19)$. Didasarkan pada BCG yang bersifat imunopotensiator, maka hipothesis dalam penelitian ini adalah "Apakah kucing yang divaksin dengan BCG setelah diinfeksi dengan M.tuberculosis akan menunjukkan aktivitas makrofag (baik dalam fagositosis maupun sekresi ROI) yang lebih tinggi dalam usahanya memberikan proteksi untuk memusnahkan M.tuberculosis yang masuk dalam tubuh kucing?"

\section{METODE}

\section{Hewan Percobaan}

Dua puluh empat kucing sehat (jenis kelamin jantan dan betina, umur 1-2 tahun, berat badan $1-2 \mathrm{~kg}$ ) dibagi secara acak dalam 2 kelompok masing-masing 12 ekor. Kelompok I yaitu kelompok yang divaksinasi dengan BCG dan kelompok II adalah kelompok kontrol yaitu kelompok yang tidak divaksin BCG. Stimulasi BCG dilakukan secara intraperitoneal, sebanyak 2 kali dengan interval 2 minggu dengan dosis $0,1 \mathrm{ml}$. Dua hari setelah vaksinasi semua kucing diinfeksi M.tuberculosis dengan dosis $10^{5} \mathrm{cfu}$ secara intraperitoneal. Mycobacterium yang digunakan dalam penelitian ini adalah M.tuberculosis galur H37Rv yang diperoleh dari Balai Laboratorium Kesehatan Daerah, Daerah Istimewa Yogyakarta.

\section{Periode waktu pemeriksaan aktivitas makrofag}

Aktifitas fagositosis makrofag peritoneum kucing diukur pada minggu ke-1, 2, 12, 24 setelah dilakukan infeksi. Pada masing-masing periode pengukuran aktivitas makrofag digunakan 3 ekor kucing, dan masing-masing kucing dibuat replikasi 3 kali.

\section{Isolasi dan kultur makrofag peritoneum}

Pada jadwal waktu yang telah ditentukan kucing dianastesi dengan menggunakan Anesject ${ }^{R}$ (kethamine) dengan dosis $0,1 \mathrm{mg} / \mathrm{kg} \mathrm{BB}$, disuntikkan secara intramuskuler. Setelah kucing tertidur, kemudian diletakkan pada posisi terlentang (dorso lateral) pada gabus yang telah dilapisi dengan aluminium foil steril, kemudian kulit bagian perut didesinfeksi dengan alkohol $70 \%$, selanjutnya kulit abdomen dibuka dengan gunting steril, sehingga tampak lapisan mesenterium dan cavum peritoneum beserta isinya dapat terlihat dengan jelas.

Medium RPMI dingin kurang lebih $100 \mathrm{ml}$ diinjeksikan ke dalam rongga peritoneum dan di-massage kurang lebih 3 menit, kemudian medium diaspirasi kembali. Aspirat yang telah diperoleh ditampung dalam tabung sentrifus steril, kemudian disentrifus pada kecepatan $1200 \mathrm{rpm}, 4^{\circ} \mathrm{C}$ selama 10 menit. Supernatan dibuang kemudian ditambahkan $3 \mathrm{ml}$ medium RPMI lengkap (mengandung FCS 10\%) pada pelet yang telah diperoleh (20).

Jumlah makrofag dihitung dengan menggunakan hemositometer kemudian diresuspensikan lagi dengan medium RPMI lengkap sehingga didapat sel dengan kepadatan $2,5 \times 10^{6} \mathrm{sel} / \mathrm{ml}$. Suspensi sel yang telah dihitung, kemudian dikultur pada sumuran microplate 24 yang telah diberi cover slips bulat, setiap sumuran $200 \mu \mathrm{l}\left(5 \times 10^{5}\right.$ sel), kemudian diinkubasi dalam inkubator $\mathrm{CO}_{2} 5 \%, 37^{\circ} \mathrm{C}$ selama 30 menit. Setelah itu ditambahkan medium RPMI lengkap sebanyak $1 \mathrm{ml}$ pada setiap sumuran kemudian diinkubasikan lagi selama 2 jam. Selanjutnya sel dicuci dengan RPMI sebanyak 2 kali, kemudian ditambahkan medium RPMI lengkap $1 \mathrm{ml}$ pada tiap sumuran dan selanjutnya diinkubasikan selama 24 jam (20).

\section{Uji Aktivitas fagositosis}

Untuk mengukur kemampuan fagositosis makrofag peritoneum kucing dilakukan dengan uji fagositosis nonspesifik secara in vitro menurut Leijh et al. (20) dengan menggunakan latex bead diameter $3 \mu \mathrm{m}$ (Sigma Chem. Co). Latex bead diresuspensikan dalam PBS sehingga didapat konsentrasi $2,5 \times 10^{7} / \mathrm{ml}$.

Setelah makrofag peritoneum kucing dikultur selama sehari (24 jam), kemudian dicuci 2 kali dengan RPMI, selanjutnya ditambahkan suspensi latex $200 \mu \mathrm{l} /$ sumuran, dan diinkubasikan selama 60 menit pada suhu $37^{\circ} \mathrm{C}, \mathrm{CO}_{2}$ $5 \%$. Kultur dikeluarkan dari inkubator kemudian dicuci dengan PBS 3 kali untuk menghilangkan partikel yang tidak difagositosis, dan kemudian dikeringkan pada suhu ruangan dan difiksasi dengan methanol absolute selama 30 detik, selanjutnya methanol dibuang dan dikeringkan pada suhu kamar. Setelah preparat kering, dilakukan pengecatan dengan Giemsa 20\% selama 30 menit. Selanjutnya hasil 
pengecatan dicuci dengan aquades, dan setelah kering cover slips diangkat dari sumuran kultur dan dikeringkan pada suhu kamar. Setelah kering ditaruh pada obyek gelas untuk dilihat di bawah mikroskop cahaya (20).

Aktivitas fagositosis makrofag dinilai dari persentase makrofag yang memfagositosis partikel latex, dihitung dari 100 makrofag yang terlihat di bawah mikroskop cahaya, dan rerata jumlah partikel latex yang difagositosis oleh setiap makrofag. Rerata jumlah partikel latex yang difagositosis oleh setiap makrofag dihitung dengan cara membagi jumlah partikel latex yang difagositosis dengan jumlah makrofag yang memfagositosis partikel latex. Sebagai contoh, bila pada saat membaca persentase makrofag yang memfagositosis partikel latex (yang dihitung dari 100 makrofag) terdapat 10 sel yang memfagositosis partikel latex dan jumlah partikel latex yang difagositosis sebanyak 30 partikel, maka rerata jumlah partikel latex yang difagositosis oleh tiap makrofag adalah 30:10 $=3$ partikel (20)

\section{Uji Sekresi ROI}

Kemampuan makrofag peritoneum kucing dalam mensekresi reactive oxygen reactive (ROI) diukur dengan nitroblue tetrazolium (NBT) reduction assay. Pada assay ini Phorbol 12-Myristate 13-Acetate (PMA) akan menstimulasi makrofag untuk mensekresi ROI, dan adanya ROI (anion superoksida, $\mathrm{O}_{2-}^{-}$) akan menyebabkan NBT tereduksi sehingga membentuk presipitat formazan yang tidak terlarut (20).

Untuk menstimulasi sekresi anion superoksida, kultur sel distimulasi dengan PMA dengan konsentrasi akhir $125 \mathrm{ng} / \mathrm{ml}$. Urutan cara kerja adalah sebagai berikut. Kultur makrofag dicuci 2 kali dengan RPMI, kemudian ditambahkan $500 \mu$ larutan NBT (1mg/ml PBS) yang mengandung $125 \mathrm{ng} / \mathrm{ml}$ PMA untuk tiap sumuran dan diinkubasikan pada incubator $\mathrm{CO}_{2} 5 \%, 37^{\circ} \mathrm{C}$ selama 1 jam. Sel kemudian dicuci dengan PBS 3 kali, dikeringkan pada suhu kamar dan difiksasi dengan methanol absolute selama 30 detik.
Setelah kering dipulas dengan 2\% Neutral Red Solution selama 15 menit, kemudian dicuci dengan aquades. Setelah kering cover slips diangkat dari sumuran microplate untuk dilihat di bawah mikroskop cahaya dengan perbesaran 400 kali (20).

Aktivitas makrofag untuk mensekresi ROI diukur dengan menghitung persentase makrofag yang mensekresi ROI yaitu yang menunjukkan pembentukan formazan (warna gelap), dihitung 100 makrofag yang terlihat dibawah mikroskop cahaya, dan skor derajat pembentukan formazan oleh tiap 100 makrofag, dihitung dengan cara menjumlahkan besarnya skor yang dicapai oleh 100 makrofag. Skor 0 jika pada makrofag tidak terbentuk formazan, skor 1 jika pada makrofag terbentuk formazan tetapi tidak memenuhi seluruh sel, dan skor 2 jika formazan yang terbentuk memenuhi seluruh sel. Sebagai contoh perhitungan skor, misalnya dari 100 makrofag terdapat 20 sel yang tidak membentuk formazan (besarnya skor 0), 40 sel membentuk formazan tetapi tidak seluruh sel (besarnya skor 40) dan 40 sel membentuk formazan (besarnya skor 80 ), maka skor pada 100 sel makrofag adalah $0+40+80=120(20)$.

\section{Analisis Data}

Untuk mengetahui efek BCG terhadap aktivitas makrofag dalam memfagositosis latex dan sekresi ROI antara kelompok perlakuan dan kontrol, data hasil penghitungan yang diperoleh dianalisis dengan menggunakan uji T (21).

Dalam interprestasi dan penghitungan jumlah sel, selalu menyertakan orang kedua untuk dapat diperoleh konfirmasi penghitungan dan interpretasi hasil yang obyektif.

\section{HASIL PENELITIAN}

Hasil foto mikroskopis aktivitas makrofag peritoneum kucing yang memfagositosis partikel latex secara in vitro pada kelompok kucing yang divaksin BCG dan kontrol (tidak divaksin) disajikan pada Gambar 1.

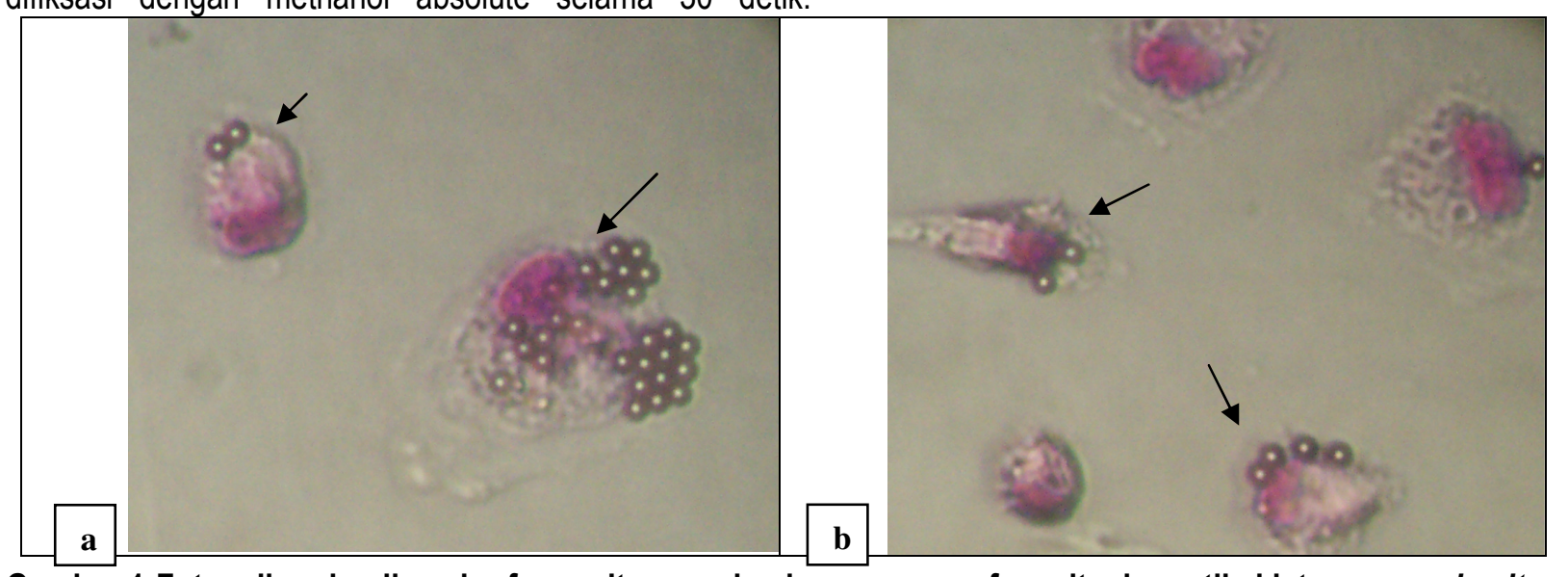

\section{Gambar 1. Foto mikroskopik makrofag peritoneum kucing yang memfagositosis partikel latex secara in vitro setelah infeksi M.tuberculosis dosis $1 \times 10^{5}$ cfu per ekor kucing (Pewarnaan Giemsa, 400x).}

Terlihat makrofag yang memfagositosis latex (a): Kelompok yang divaksin BCG (b): Kelompok kontrol. Tanda panah menunjukkan partikel latex yang difagositosis oleh makrofag. 
Hasil kemampuan aktivitas fagositosis makrofag kelompok kucing yang divaksin BCG dan kelompok kucing kontrol setelah diinfeksi dengan M.tuberculosis disajikan pada Gambar 2 dan 3. Seperti terlihat pada Gambar 2 aktivitas fagositosis yang dinilai dari persentase makrofag yang memfagositosis latex, menunjukkan bahwa persentase fagositosis kelompok kucing yang divaksin BCG lebih tinggi dibandingkan dengan kelompok kontrol. Gambaran pola presentase makrofag yang memfagositosis latex bead menunjukkan adanya kecenderungan adanya peningkatan pada minggu pertama dan mencapai puncaknya pada minggu kedua, kemudian diikuti penurunan aktivitas sesuai dengan berjalannya waktu sampai akhir penelitian. Hal yang serupa nampaknya juga terlihat pada pola hasil penghitungan rata-rata latex yang difagositosis oleh setiap makrofag (Gambar 3). Rata-rata latex yang difagositosis lebih tinggi pada kelompok kucing yang divaksin BCG dibanding dengan kelompok kontrol, dan puncak rata-rata tertinggi latex yang difagositosis makrofag mencapai puncaknya pada minggu kedua setelah infeksi.

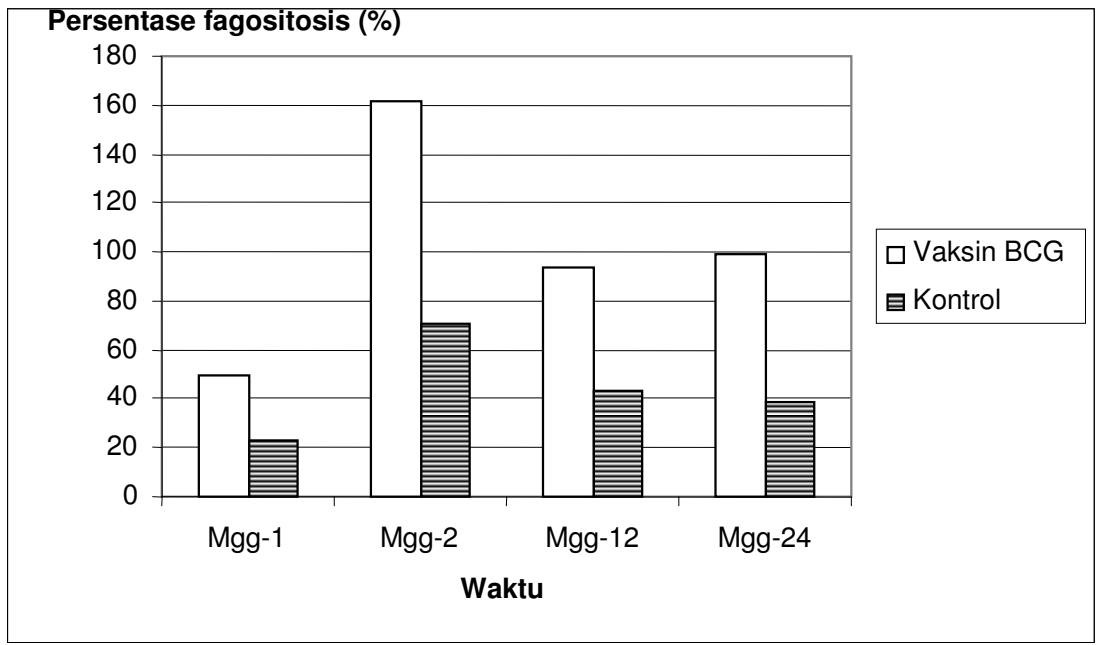

Gambar 2. Rata-rata persentase makrofag yang memfagositosis latex kelompok kucing yang divaksin BCG dan kelompok kontrol, setelah diinfeksi M.tuberculosis dosis $10^{5} \mathrm{cfu}$

Latex yang difagositosis makrofag

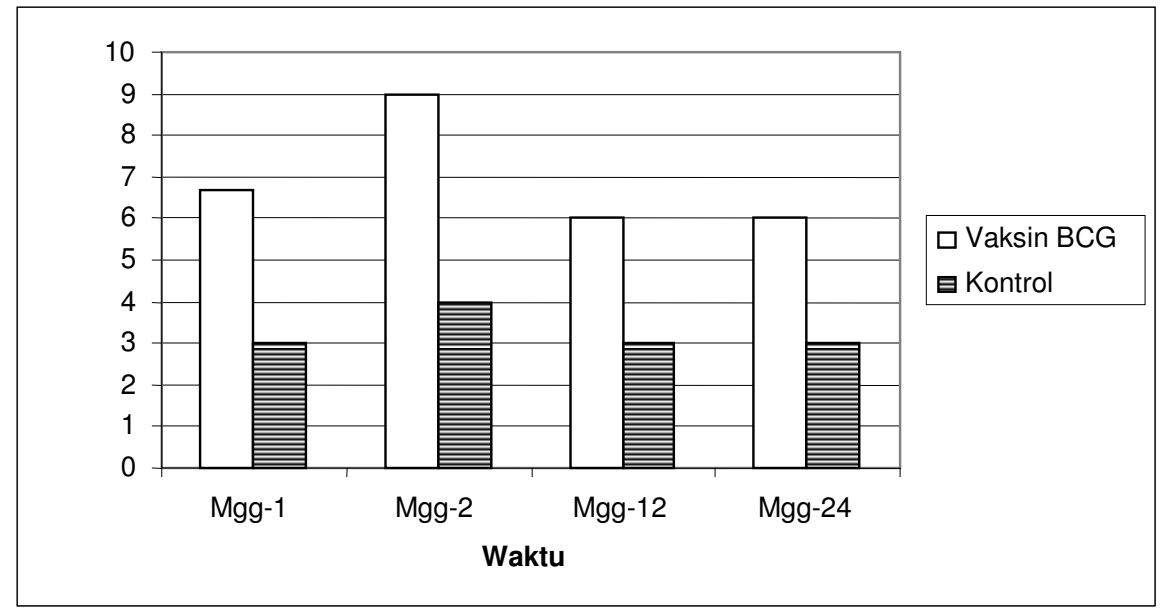

Gambar 3. Rata-rata latex yang difagositosis oleh makrofag kelompok kucing yang divaksin BCG dan kelompok kontrol, setelah diinfeksi M.tuberculosis dosis $10^{5} \mathrm{cfu}$

Aktivitas makrofag peritoneum kucing yang mensekresi ROI diukur dengan NBT reduction assay, dan diukur dari dua aspek yaitu persentase makrofag yang mensekresi ROI dan dari skor derajat pembentukan formazan. Hasil foto mikroskopis aktivitas makrofag peritoneum kucing yang mensekresi ROI pada kelompok kucing yang divaksin BCG dan kontrol (tidak divaksin) disajikan pada Gambar 4. 


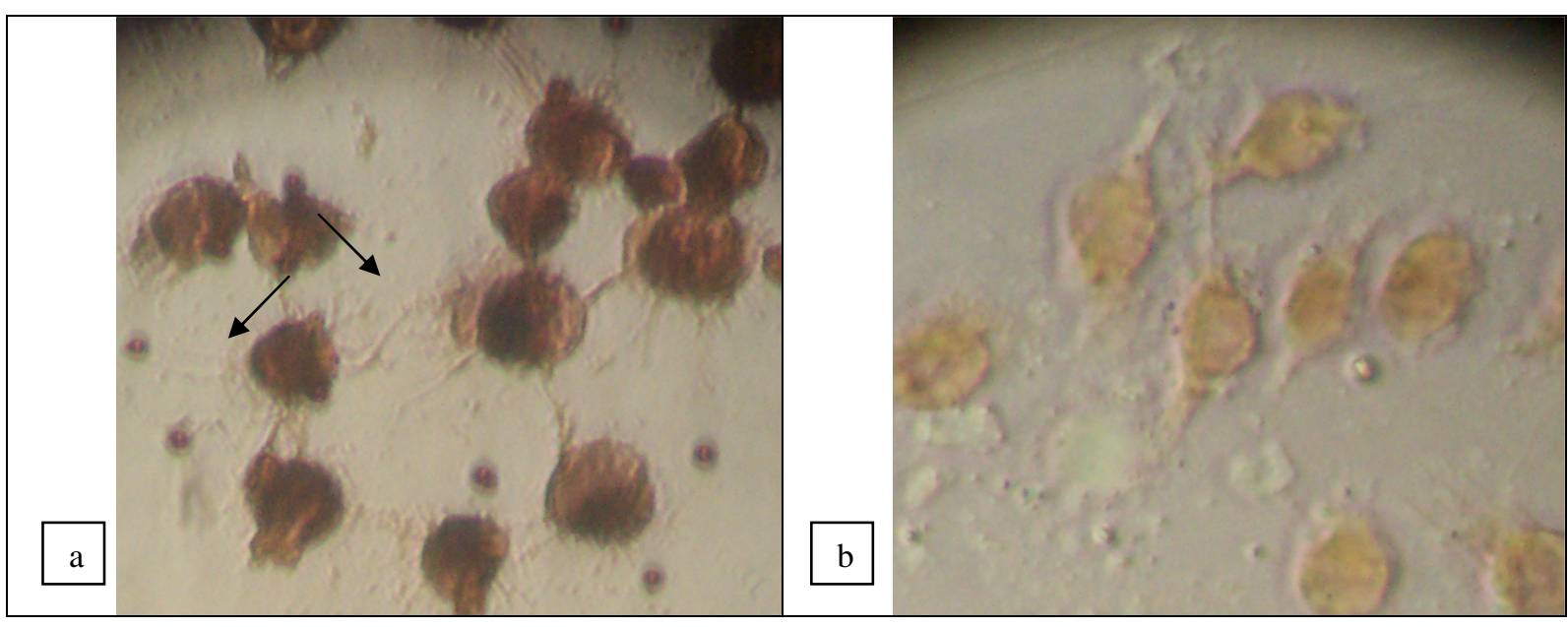

Gambar 4. Foto mikroskopik makrofag peritoneum kucing yang mensekresi ROI setelah infeksi M.tuberculosis dosis $1 \times 10^{5}$ cfu per ekor kucing (Pewarnaan Neutral Red, 400x).

Terlihat makrofag yang mensekresi ROI (a): Kelompok yang divaksin BCG (b): Kelompok kontrol. Tanda panah menunjukkan formazan pada makrofag yang mensekresi ROI.

Hasil kemampuan aktivitas sekresi ROI makrofag kelompok kucing yang divaksin BCG dan kelompok kucing kontrol setelah diinfeksi dengan M.tuberculosis disajikan pada Gambar 5 dan 6 . Seperti terlihat pada Gambar 5 aktivitas sekresi $\mathrm{ROI}$ yang dinilai dari persentase makrofag yang mensekresi ROI, menunjukkan bahwa persentase makrofag yang mensekresi ROI kelompok kucing yang divaksin BCG lebih tinggi dibandingkan dengan kelompok kontrol. Gambaran pola presentase makrofag yang mensekresi ROI menunjukkan adanya kecenderungan adanya peningkatan pada minggu pertama dan mencapai puncaknya pada minggu kedua, kemudian diikuti penurunan aktivitas sekresi sesuai dengan berjalannya waktu sampai akhir penelitian.

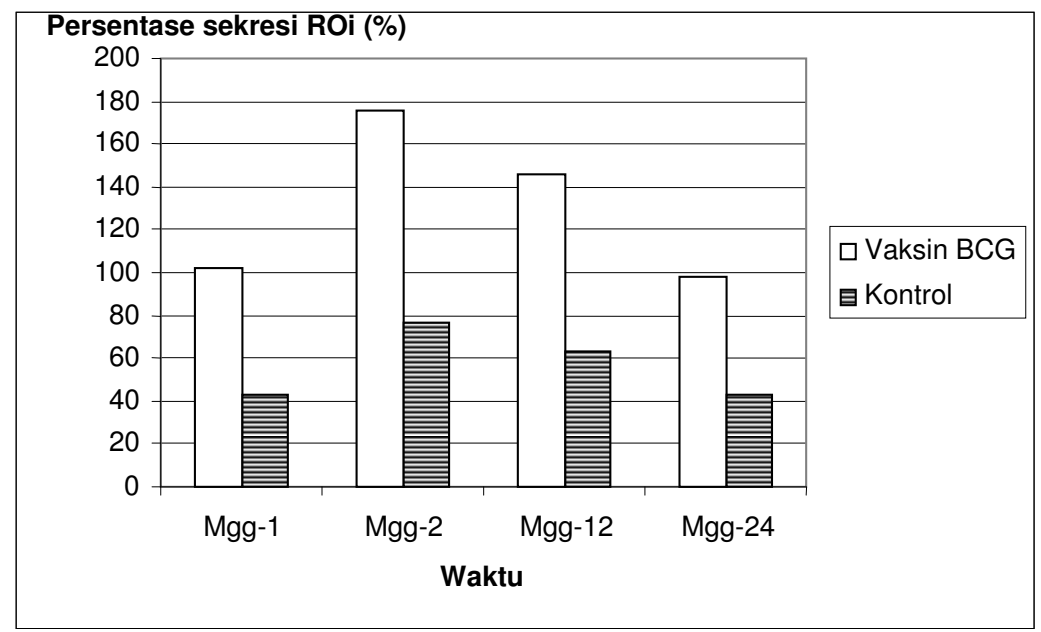

Gambar 3. Rata-rata persentase makrofag yang mensekresi ROI kelompok kucing yang divaksin BCG dan kelompok kontrol, setelah diinfeksi M.tuberculosis dosis $10^{5} \mathrm{cfu}$

Hasil penghitungan skor ROI nampaknya memberikan gambaran yang serupa dengan persentase makrofag yang mensekresi ROI (Gambar 6). Skor ROI yang disekresi oleh makrofag (formazan yang terbentuk) diperoleh lebih tinggi pada kelompok kucing yang divaksin BCG dibanding dengan kelompok kontrol, dengan puncak tertinggi skor ROI pada minggu kedua setelah infeksi. Setelah minggu kedua, skor ROI berangsur-angsur menurun sesuai berjalannya waktu dan tetap lebih tinggi dibanding dengan kelompok kontrol sampai akhir penelitian. 


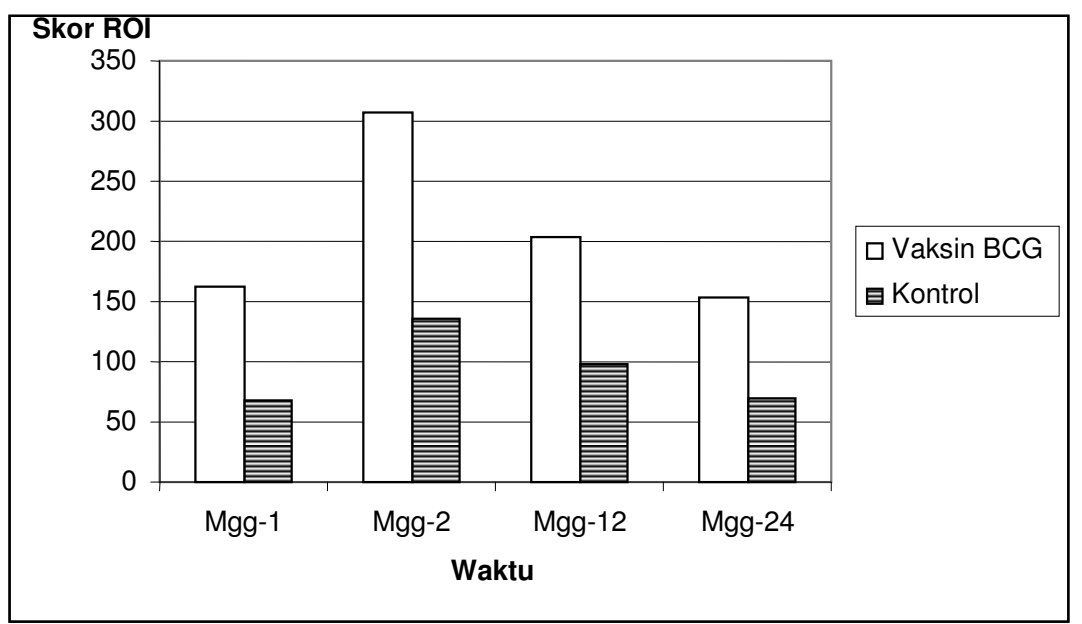

\section{Gambar 4. Rata-rata skor ROI makrofag kelompok kucing yang divaksin BCG dan kelompok kontrol, setelah diinfeksi M.tuberculosis dosis $10^{5} \mathrm{cfu}$}

\section{DISKUSI}

Hasil analisis dengan uji $\mathrm{T}$ terhadap aktivitas fagositosis oleh makrofag menunjukkan bahwa terdapat perbedaan yang bermakna $(P<0,01)$ antara persentase makrofag yang memfagositosis latex pada kelompok yang divaksin BCG dan kelompok kontrol yang tidak divaksin BCG. Demikian juga hasil analisis terhadap rata-rata latex yang difagositosis oleh tiap makrofag, menunjukkan adanya perbedaan yang bermakna $(P<0,01)$ antara kelompok kucing yang divaksin dan yang tidak divaksin BCG.

Dari hasil tersebut menunjukkan bahwa adanya vaksinasi BCG dapat meningkatkan aktivitas fagositosis makrofag peritoneum kucing secara signifikan. Menurut Hennesey (10) BCG merupakan imunopotensiator yang dapat menstimulasi imunitas seluler dengan mengaktifkan aktivitas sel $T$ dan makrofag dengan berbagai mekanisme. Demangel et al. (I2) membuktikan bahwa pemberian BCG secara in vitro dapat memacu maturasi sel-sel dendritik (APC, antigen precenting cell) yang ditunjukkan dengan adanya peningkatan ekspresi antigen $\mathrm{MHC} \mathrm{II}$, dan molekul kostimulator CD80 dan CD86. Hasil penelitian mengenai efek BCG pada aktivitas makrofag pada tikus BAL/c yang diinfeksi dengan Sthaphylococcus aureus telah dilaporkan oleh Djamiatun et al. (13). Demikian juga efek BCG dapat meningkatkan daya bunuh terhadap infeksi Toxoplasma gondii pada mencit telah dilaporkan oleh Muthmainah (22). Data aktivitas fagositosis makrofag peritoneum kucing penelitian yang diperoleh membuktikan bahwa vaksinasi BCG pada kucing dapat meningkatkan aktivitas fagositosis makrofag. Atau dengan kata lain BCG dapat bertindak sebagai imunopotensiator yaitu dengan meningkatkan secara bermakna kemampuan fagositosis makrofag dalam usahanya untuk memuskahkan M.tuberculosis yang masuk pada tubuh kucing.

Hasil analisis dengan uji T terhadap aktivitas sekresi $\mathrm{ROI}$ oleh makrofag menunjukkan bahwa terdapat perbeda- an yang bermakna $(P<0,01)$ antara persentase makrofag yang mensekresi ROI pada kelompok yang divaksin BCG dan kelompok kontrol yang tidak divaksinasi BCG. Demikian juga hasil analisis terhadap skor ROI yang disekresi oleh makrofag, menunjukkan adanya perbedaan yang bermakna $(P<0,01)$ antara kelompok kucing yang divaksin dan yang tidak divaksin BCG.

Dari hasil tersebut menunjukkan bahwa vaksinasi BCG pada kucing dapat meningkatkan aktivitas makrofag dalam sekresi ROI dalam usahanya untuk memusnahkan M.tuburculosis yang masuk pada tubuh kucing. Hasil penelitian terdahulu menunjukkan bahwa adanya infeksi $M$. tuberculosis pada kucing meningkatkan sekresi $\mathrm{ROI}$ oleh makrofag dan mencapai puncaknya pada minggu kedua setelah infeksi, yang dihubungkan dengan mekanisme pembunuhan efektif terhadap M.tuberculosis (23). Peningkatan aktivitas makrofag dalam sekresi ROI yang mencapai puncaknya pada minggu kedua setelah infeksi, juga didukung dengan hasil penelitian berikutnya yang menunjukkan bahwa pada minggu kedua setelah infeksi selain aktivitas sekresi ROI yang mencapai puncak, aktivitas makrofag dalam fagositosis juga mencapai puncaknya pada waktu yang sama (24). Reactive oxygen intermediate merupakan produk oksidatif makrofag yang memainkan peranan penting dalam mekanisme pembunuhan $M$. tuberculosis, yang aktivitasnya diinduksi oleh sitokin IFN-y dan TNF-a $(25,26)$. Kemampuan BCG dalam menstimulasi respon imun seluler khususnya dalam mekanisme sebagai efektor oksidatif pada mencit telah banyak dilaporkan. Supargiono (14) mendemontrasikan peningkatan aktivitas oksidatif makrofag mencit dalam membunuh intraerythrocytic Plasmodium yoelli secara in vitro. Percobaan serupa juga telah dilakukan oleh Shear cit Wijayanti (15) dalam pembunuhan Plasmodium knolesi, dan dalam pembunuhan Plasmodium berghei (15). Aktivitas pembunuhan oksidatif terhadap Toxoplasma gondii juga telah dila- 
porkan oleh Muthmainah (22). Dari data hasil aktivitas makrofag peritoneum kucing yang diperoleh, membuktikan bahwa BCG juga mampu meningkatkan respon imun pada kucing melalui peningkatan aktivitas sekresi $\mathrm{ROI}$ dalam usahanya memproteksi untuk memusnahkan M.tuberculosis yang masuk dalam tubuh kucing.

\section{KESIMPULAN}

Dari hasil dan diskusi tersebut di atas maka dapat disimpulkan bahwa vaksinasi BCG pada kucing dapat meningkatkan secara bermakna respon imun seluler, yaitu melalui peningkatan aktivitas makrofag baik dalam aktifitas fagositosis maupun sekresi ROI. Pengaruh peningkatan aktivitas makrofag terlihat sejak awal infeksi M.tuberculosis sampai akhir penelitian, hal ini dapat diartikan bahwa dampak perlindungan pengaruh vaksinasi BCG yang diberikan dapat dipertahankan dalam waktu yang lama, yang diharapkan dalam aplikasinya di lapangan dapat memberikan perlidungan yang efektif terhadap infeksi kuman tersebut.

\section{UCAPAN TERIMAKASIH}

Penulis mengucapkan terimakasih kepada yang terhormat Prof. Dr. Marsetyawan HNE, Prof. Dr. Supargiono, dan dr.Yanri Wijayanti Subronto, Ph.D. Fakultas Kedokteran, Universitas Gadjah Mada, yang telah banyak memberikan petunjuk, masukan, dan saran, selama melakukan penelitian, sehingga beberapa kendala selama penelitian dapat teratasi. Ucapan terimakasih juga penulis haturkan kepada Kepala Laboratorium Hayati, Universitas Gadjah Mada, yang telah memberikan ijin dan fasilitas selama penelitian, dan Drh. Wieklati, MS., selaku Kepala Bagian Mikrobiologi, Balai Laboratorium Kesehatan Daerah, Daerah Istimewa Yogyakarta, yang telah memberikan bantuan untuk memperoleh isolat dan fasilitas selama penelitian. Penulis juga mengucapkan terimakasih kepada Sdr. Suprihatin yang telah membantu selama penelitian berlangsung, dan semua pihak yang tidak dapat penulis sebutkan satu persatu, sehingga selesainya penelitian ini.

\section{DAFTAR KEPUSTAKAAN}

1. Raviglione MC, Snider Jr DE, and Kochi A. Global Epidemiologu of Tuberculosis: Morbidity and Mortality of a Wordwide Epidemic. JAVMA 1999; 273; 220-226.

2. Dolin JP. Global Tuberculosis Incidencs and Mortality during 1990-2000. Buletin World Health Organization 1994; 72 : (2): 213-220.

3. Manaf A. Permasalahan Pemberantasan Tuberkulosis di Indonesia. Seminar Nasional Tuberkulosis dan Lepra. Yogyakarta: Pusat Kedokteran Tropis Universitas Gadjah Mada; 1997.

4. Snider WR. Tuberculosis in Canine and Feline: Review of the literature. American Review Respiratory 1971; 104: 877887.

5. Anonim. The Merck Veterinary Manual. A Handbook of Diagnosis, Therapy, and Disease Prevention and Control for the Veterinarian. 8th Ed. USA: Merck and Co., Inc. Rhaway NJ; 1998; 492.

6. Bennet M and Gaskell RM. Feline and Canine Infectious Diseases. Berlin, Germany: Blackwell Wissenschafts-verlag GmbH kurfurstendamm; 1996; 130-132.

7. Montali RJ, Mikota SK, and Cheng II. Mycobacterium Tuberculosis in Zoo and Wildlife Species. Rev. sci Tech., 2001; 291-303.

8. Huebner RE dan Comstock GW. BCG Vaccine. In: Friedman, L.N. Ed. Tuberculosis Current Concepts and Treatment. Florida: CRS Press; 1994; 335-344.

9. Huebner RE. BCG Vaccination in the Control of Tuberculosis. In: Shinnick, T.M. Ed. Tuberculosis. Berlin: Springer; 1996; 263-279.

10. Hennesey LR dan Baker JR. Immunomodulator dalam Basic and Clinical Immunology. Ed. Stites DP, Terr Al, $8^{\text {th }}$ Ed. Conecticut: Appleton and Lange; 1994; 781-785.

11. Yaqoob P dan Calder PC. The Effect of Dietary Lipid Manipulation on The Production of murine T-cell Derived Cytokine. Cytokine; 1995; 7: 548-553.

12. Demangel C, Bean AG, Martin E, Feng CG. Protection Against Aerosol Mycobacterium tuberculosis using Mycobacterium bovis Bacillus Calmette-Guerin infected dendritic cell. Eur. J. Immunol 1999; 29 (6): 1972-1979.

13. Djamiatun K, Dharmana E, Kristina T, Indar R. Pengaruh vitamin A dan BCG pada produksi TNF-a dan aktivitas fagositosis makrofag terhadap Staphylococcus aureus. Laporan Akhir Tahun I Risbin Iptekdok. Yogyakarta: Fakultas Kedokteran, Univesitas Gadjah Mada. 1998.

14. Supargiono. Production, Proliferation and Functional Activities of Mononuclear Phagocytes during Plasmodium vinkei petteri Infection in Mice. [PhD Thesis] London, UK: King's College; 1993; 37. 
15. Wijayanti MA. Peranan makrofag dalam imunitas terhadap infeksi malaria: Kajian kemampuan fagositosis dan sekresi ROI makrofag peritoneum mencit yang diimunisasi dan tidak diimnisasi in vitro. [Thesis]. Yogyakarta: Program Studi IImu Kedokteran Tropis, Pascasarjana, Universitas Gadjah Mada. 1996.

16. Tjahajati I, Prodjoharjono S, Soebono H, Asmara W, Subronto YW dan Harada N. Profil Sitokin Th1-Th2 Terhadap Infeksi M.tuberculosis pada Kucing. Media Medika Indonesiana 2004; 39(3):137-145.

17. Graham A, Rook W, dan Bloom BR. Mechanism of Phathogenesis in Tuberculosis. In: Tuberculosis Pathogenesis and Control. Bloom, B.R. Editor. Washington, DC: American Society for Microbiology; 1994; 485-502.

18. Ryan JL. Bacterial Disease in Medical Immunology, $9^{\text {th }}$ Ed. Stites DP, Terr Al, Parslow TG. London: Prentice-Hall International Inc; 1997; 627-636.

19. Flyn JL, and Chan J. Immunology of Tuberculosis. Annu.Rev.Immunol 2001; 19: 93-129.

20. Leijh PCJ, Furh RV, dan Zwet TLV. In Vitro Determination of Phagocyte and Intracellular Killing by Polymorphonuclear and Mononuclear Phagocyte. In: Weir DM Ed., Cellular Immunology. London: Blackwell Scientific Publication; 1986; 46.1 $-46.21$.

21. Kinnear PR and Gray CD. SPSS for Window Made Simple, 3 $3^{\text {rd }}$ Ed. Lawrence Erbaum, 1999.

22. Muthmainah. Studi tentang aktivitas makrofag mencit yang distimulasi dengan protein soluble Toxoplasma dan BCG selama infeksi Toxoplasma gondii. [Thesis]. Yogyakarta: Program Studi Ilmu Kedokteran Tropis, Pascasarjana, Universitas Gadjah Mada. 2002.

23. Tjahajati I, Prodjoharjono S, Soebono H, Asmara W, dan Harada N. Aktivitas Sekresi Reactive Oxygen Intermediate (ROI) pada Makrofag Peritoneum Kucing yang Diinfeksi dengan M.tuberculosis. Yogyakarta: Journal Sain Veteriner 2004' , Vol XXII (1):46-53.

24. Tjahajati I, Prodjoharjono S, Soebono H, Asmara W, dan Harada N. Peningkatan Aktivitas Fagositosis pada Makrofag Peritoneum Kucing yang Diinfeksi dengan M.tuberculosis. Yogyakarta: Journal Sain Veteriner 2004c, Vol XXII (2):61-65.

25. Barnes P, Modlin RL and Ellner JJ. T-cell responses and cytokines. In: B Bloom, editor. Tuberculosis: Pathogenesis, Protection, and Control. Washington, DC: ASM Press; 1994, 417-435.

26. Akaki T, Tomioka H, Shimizu, Dekio S, dan Sato K. Comparative Roles of Free Fatty Acids with Reactive Nitrogen Intermediates and Reactive Oxygen Intermediates in Expression of the Anti-Microbial Activity of Macrophages Agains Mycobacterium tuberculosis. Clinical \& Experimental Immunology 2000; 121: 320-332. 